\title{
УГОА ЗРЕНИЯ
}

DOI 10.15826/izv1.2020.26.4.084

Е. А. Бабошин

УДК 070.1:342.413 + 342.849

Р. Л. Исхаков

В. В. Лашко

\section{О КОНСТИТУЦИОННОМ ДИСКУРСЕ 2020 г. И ЛЕГИТИМАЦИИ РОССИЙСКОЙ ГОСУДАРСТВЕННОСТИ}

Показано участие средств массовой информации 1 июля 2020 г. в процессе подготовки и проведения голосования по поправкам в Конституцию РФ. На основе предложенной М. Вебером типологии легитимации разработаны легитимирующие апелляции конституционного дискурса, которые способствуют формированию российской национальной идентичности.

К л юч е в ы е с л о в а: поправки в Конституцию РФ; общероссийское голосование; дискурс; легитимирующие апелляции; нациеобразование

Российские средства массовой информации (СМИ) в первом полугодии 2020 г. были включены в механизм обсуждения поправок в действующую Конституцию РФ, принятую всенародным голосованием 12 декабря 1993 г. [20].

В начале XXI в. действующие политики, отечественные ученые-обществоведы обратили внимание на проблемы легитимации национальной государственности. В 2012 г. в нашей стране отметили 1150-летие зарождения российской государственности, вышел соответствующий Указ Президента РФ о праздновании этого события [13]. В научном и экспертном сообществе актуализировались дискуссии

БАБОШИН Егор Александрович - студент департамента политологии и социологии Уральского федерального университета (e-mail: babosh_99@mail.ru).

ИСХАКОВ Рафаиль Лутфуллович - кандидат филологических наук, доцент, доцент кафедры периодической печати и сетевых СМИ Уральского федерального университета, членкорреспондент Академии энциклопедических наук (e-mail: rafail.iskhakov@urfu.ru). ORCID: 0000-0002-9655-7086.

ЛАШКО Виктория Викторовна - юрист, председатель Кировской районной территориальной избирательной комиссии г. Екатеринбурга (e-mail: ekr@ik66.ru).

() Бабошин Е. А., Исхаков Р. Л., Лашко В. В., 2020 
вокруг вопроса о формировании современной российской нации. На заседании Совета по межнациональным отношениям в Астрахани 31 октября 2016 г. бывший руководитель Министерства по делам Федерации, национальной и миграционной политики РФ (1995-2000) В. А. Михайлов предложил разработать Закон «О единстве российской нации и управлении межэтническими отношениями».

Российский конституционализм в конце второго десятилетия ХХІ в. несколько раз напомнил о себе круглыми датами: в 2017 г. Конституции РСФСР 1937 г. исполнилось 80 лет, в 2018 г. самой первой Конституции (1918 г.) исполнилось 100 лет, Основному закону 1978 г. - 40 лет, действующей Конституции Российской Федерации - 25 лет.

Говоря о конституционализме, мы имеем в виду лишь один вопрос: речь идет об инклюзивности (включенности) средств массовой информации в формировании оснований государственной власти.

Первым в отечественной науке концептуальным обобщенным исследованием современной конституции стала монография Т. Я. Хабриевой и В. Е. Чиркина «Теория современной конституции» [28]. Формы и методы участия СМИ в конституционном процессе, охватывающем законодательный, избирательный, правотворческий и парламентский процессы (но не сводимом ни к одному из них), в разное время рассматривали Е. П. Прохоров, С. Г. Корконосенко, А. А. Тертычный, И. Д. Фомичева, А. Г. Менделеев и др.

Анализ участия СМИ в обсуждении поправок в Конституцию представляет собой заполнение научной лакуны. Ранее участие СМИ в плебисцитах никак не регулировалось нормами права. Однако СМИ неоднократно принимали участие в избирательных кампаниях, т. е. осуществляли информационное обеспечение выборов.

Поэтому как общественному мнению, так и сознанию отдельных авторов было трудно преодолеть стереотипы, связанные с избирательными кампаниями (участие СМИ проходило в формах а) информирования избирателей, б) предвыборной агитации и в) обеспечения гласности выборов). Эти стереотипы основывались на нормах действующего избирательного законодательства, формы закреплялись на местах подзаконными актами, в частности Избирательным кодексом Свердловской области (ст. 59).

Однако голосование по поправкам в Конституцию было чем-то новым в правовой практике. Оно даже не имело своего названия. Председатель ЦИК РФ Э. А. Памфилова предложила специальный термин для голосования по поправкам в Конституцию РФ - «общероссийское голосование» [16].

Оно не было референдумом, который согласно п. 3 ст. 3 Конституции РФ является высшим непосредственным выражением власти народа и регулируется специальным Федеральным конституционным законом от 28.06. 2004 г. № 5-ФКЗ (ред. от 18.06. 2017 г.) «О референдуме Российской Федерации».

Поправки в совокупности и каждая из них в отдельности, как отметил Президент РФ В. В. Путин, не затрагивают фундаментальных основ Конституции, а значит, могут быть утверждены парламентом с помощью конституционных законов. Но поскольку они существенно меняют политическую систему, по всему пакету предложенных поправок нужно провести голосование граждан «и только 
по его результатам принимать решения». Требование общественного согласия прямо указывает на то, что во властной элите существует понимание того, что легитимация государственности, утвержденной в действующей Конституции, возможна лишь в результате дискурса.

Как процедуру, так и результат обсуждения мы называем термином «конституционный дискурс». Его масштабы демонстрирует поисковая платформа Googl, которая по запросу «обсуждение поправок в Конституцию» 26 августа 2020 г. нашла 2,7 млн ссылок, в информационно-аналитической системой мониторинга и анализа СМИ «Медиалогия» было обнаружено 95,0 тыс. ссылок. Несомненно, контент этого информационного потока заслуживает отдельного научного рассмотрения.

Конституционный дискурс 2020 г. предстал как тип коммуникации, где диалогическая речь противостоит монологической. Этот тип давно и основательно изучали лингвисты, а диалогические связи между персонажами как важный компонент художественного текста и «диалоги» как особый жанр - литературоведы. Инклюзивность СМИ в политический процесс делает актуальным рассмотрение в теории журналистики форм и методов их участия в легитимации государственной власти.

Коммуникация, по Юргену Хабермасу, имеет двойную структуру, две формы: коммуникативное действие и дискурс $[32,107]$. В коммуникативном действии значение смысловых связей лишь предполагается, так как главное - обмен информацией. В дискурсе значения смысловых связей становятся основной темой, но обмена информацией не происходит.

Дискурс является необходимым дополнением понимания между субъектами. Дискурс в коммуникативной теории Хабермаса имеет то же значение, что и традиция в герменевтике: здесь дискурс как метод позволяет на основе языковой способности прийти к соглашению, взаимопониманию в любом социальном действии, в любой языковой ситуации. Две формы коммуникации взаимодействуют между собой.

Дискурс - это не только форма организации познания, но и форма политической деятельности [3, 139]. Хабермас стремится к тому, чтобы «планирующие инстанции» учитывали «дискурсивное образование воли». По его мнению, дискурс - это диалог всех со всеми. В идее дискурса Хабермаса, как считали советские философы, находит выражение «идеализация буржуазного парламентаризма» [Там же, 141].

Конституционный дискурс - микст (смешение) взаимодействия интеллектуального и социального полей, где дискурсивное поле переходит в определенный тип практики [7]. В центре дискурсивного поля в ходе обсуждения поправок в Основной закон стояла сама Конституция РФ. По многим позициям возникла общенародная дискуссия.

Различны функции участия средств массовой информации в обсуждении Конституции, ее проекта. СМИ не обладают ни силой государственного принуждения, ни возможностями экономического давления. Их «властные полномочия» лежат в сфере духовно-идеологической, в сфере влияния (причем степень реального влияния может быть очень разной в зависимости от множества 
обстоятельств). Журналистика располагает в соответствии со своей природой многообразной специфической системой «властных полномочий», что само по себе и дает основания говорить о ней действительно как о «четвертой власти».

Есть два основания российской, как и любой другой, государственности - юридическое (легализация, законность) и социально-психологическое (легитимация, т. е. ее обоснованность в представлениях населения) [31]. Поскольку согласно ст. 3 действующей Конституции РФ носителем суверенитета и единственным источником власти является многонациональной народ Российской Федерации, то он единственный участвует и в ее легализации, и в ее легитимации.

Легализация и легитимация едины в своей государственно-правовой природе, как писал российский ученый-правовед, специалист по теории государства и права, конституционному праву В. Е. Чиркин (1924-2019) [Там же].

Первый его тезис - государственная власть нуждается в узаконивании. Легализация (от лат. legalis - законный) в русском языке означает процесс действия по глаголу «легализовать» («легализировать», «легализоваться»), а также результат такого действия. Термин означает «узаконивать, признать (признавать) законным» [26, 310]. Легализация государственной власти - понятие юридическое.

Конституция России состоит из 9 глав, из которых 1-я, 2-я и 9-я неизменяемы (Конституция РФ, ст. 135. п. 1). Главы 3-8 могут изменяться, но согласно ст. 136 Конституции для этого нужно согласие субъектов Федерации, Государственной думы, Совета Федерации, Президента.

В послании Федеральному собранию 15 января 2020 г. Президент РФ В. В. Путин предложил внести поправки в Конституцию России [17]. За время действия Конституции было проведено несколько изменений. Первые серьезные изменения вступили в силу в декабре 2008 г. Следующий пакет поправок был принят в феврале 2014 г. В июле 2014 г. вступили в силу изменения, касающиеся Совета Федерации. Также в Конституцию вносились изменения, связанные с образованием или ликвидацией субъектов Федерации и с их переименованием [10].

В процессе легализации СМИ выполняют присущую им пропагандистскую функцию, которую зачастую продолжают отождествлять с отсутствием объективности, неприятием политического плюрализма, бессовестной трескотней. Однако хочется думать, что с движением страны к гражданскому обществу все эти признаки ушли в прошлое из отечественных СМИ. Глубинная суть пропагандистской функции СМИ, определяемой как постоянное целенаправленное воздействие на аудиторию с целью утверждения определенного образа жизни, политических и духовно-нравственных ценностей, остается.

Более сложным является понятие легитимации государственной власти. В основе слова «легитимация» лежит тот же латинский корень, но термину дается иное истолкование. Второе определение профессора В. Е. Чиркина - это тоже узаконение, но узаконение уже главным образом не правовое, и даже не имеющее отношение к праву. Легитимация государственной власти представляет собой делегирование, передачу власти обществом его особой организации - государству, его структурам. Следствие легитимации государственной власти - ее авторитет. 
Будучи включенными в процесс легитимации, СМИ выполняют непосредственно-организаторскую функиию [19] в целях самоидентификации граждан нашей страны. Она проявляется при выполнении чисто журналистских задач: проведение «круглых столов» в печатной периодике, организация радиоперекличек и радиомитингов, телевизионных программ с привлечением массовой аудитории (от телемостов до ток-шоу).

СМИ в январе - июле 2020 г. информировали граждан России о формировании пакета поправок в Конституцию, освещали подготовку законопроекта о поправках, его прохождение в инстанциях и принятие, а также голосование по поправкам и обнародование его результатов. Нами было проанализировано 69 текстов из 31 источника по теме «Поправки к Конституции РФ» (табл. 1).

Таблица 1

Публикации на тему «Поправки к Конституции РФ»

\begin{tabular}{|c|c|c|}
\hline СМИ & Количество & $\%$ \\
\hline «Ведомости» & 10 & 15,0 \\
\hline Znak.com & 6 & 8,7 \\
\hline «КоммерсантЂ» & 6 & 8,7 \\
\hline РБК & 6 & 8,7 \\
\hline Meduza.io & 5 & 7,2 \\
\hline РИА «Новости» & 4 & 5,9 \\
\hline TACC & 3 & 4,3 \\
\hline «Медиазона» & 3 & 4,3 \\
\hline «Новая газета» & 3 & 4,3 \\
\hline BBC News. Русская служба & 3 & 4,3 \\
\hline Kremlin.ru. & 2 & 2,9 \\
\hline «Российская газета» & 2 & 2,9 \\
\hline Newsru.com & 2 & 2,9 \\
\hline anews.com & 1 & 1,4 \\
\hline forbes.ru & 1 & 1,4 \\
\hline Lenta.ru. & 1 & 1,4 \\
\hline mos.news & 1 & 1,4 \\
\hline svoboda.org & 1 & 1,4 \\
\hline ИА «Амител» & 1 & 1,4 \\
\hline ИА «Телеграф» & 1 & 1,4 \\
\hline ИА REGNUM & 1 & 1,4 \\
\hline ИА «Хакасия» & 1 & 1,4 \\
\hline «Фонтанка» (интернет-газета, Санкт-Петербург) & 1 & 1,4 \\
\hline «Газета.Ru» (интернет-издание) & 1 & 1,4 \\
\hline «ГОРДОН» (интернет-издание) & 1 & 1,4 \\
\hline «Левый Фронт» (Москва) & 1 & 1,4 \\
\hline «Между строк» (агентство новостей) & 1 & 1,4 \\
\hline
\end{tabular}


Окончание табл. 1

\begin{tabular}{l|c|c}
\hline \multicolumn{1}{c|}{ СМИ } & Количество & $\%$ \\
\hline Международное радио «RFI» (Франция) & 1 & 1,4 \\
Радиостанция «Эхо Москвы» & 1 & 1,4 \\
«Русская планета» & 1 & 1,4 \\
«Свободная пресса» & 1 & 1,4 \\
Итого & 69 & 100,0
\end{tabular}

На сайте Государственной думы РФ был опубликован полный текст Закона «О поправке к Конституции Российской Федерации» - «О совершенствовании регулирования отдельных вопросов организации и функционирования публичной власти», вынесенный на общенародное голосование, со сравнительной таблицей действующей Конституции РФ (http://duma.gov.ru/news/48045/). Все 206 изменений затрагивают главы 3-8 Основного документа (о федеративном устройстве, президенте, парламенте, правительстве, судебной власти и прокуратуре, местном самоуправлении) [6].

Президент, депутаты ГД и члены Совета Федерации 2 марта 2020 г. внесли на рассмотрение второй пакет поправок в Конституцию. Ответственным комитетом Государственной думы 170 поправок были рекомендованы к принятию, 169 - к отклонению. Окончательно поправки во втором чтении затронули сорок одну статью Конституции, с 3-й по 8-ю главу ${ }^{1}$.

Во втором чтении в Государственной думе за внесение поправок проголосовали 382 депутата, 34 (КПРФ) - воздержались, против - нет. 11 марта Государственная дума приняла в третьем чтении и направила на рассмотрение в Совет Федерации поправки в Конституцию, принятые во втором чтении с некоторыми малыми изменениями. В Совете Федерации за закон о поправках проголосовало 160 чел. (из 164 голосовавших, 94,1%). Поправки (206 изменений) были приняты в качестве Закона о поправках от 14 марта 2020 г. № 1-ФКЗ «О совершенствовании регулирования отдельных вопросов организации и функционирования публичной власти» [14]. Конституционный суд подтвердил соответствие поправок Конституции РФ [5]. Согласно п. 5 ст. 3 Закона, коррективы вступают в силу в случае их одобрения большинством участников общероссийского голосования.

Изначально голосование должно было состояться 22 апреля, однако было отложено на неопределенный срок из-за пандемии коронавируса. Голосование проводилось согласно особому порядку. На данный плебисцит не распространялось действие федеральных законов «Об основных гарантиях избирательных прав и права на участие в референдуме граждан Российской Федерации» (далее «гарантийный» закон. - Авт.) и «О референдуме...».

Общероссийское голосование по вопросу одобрения изменений в Конституцию Российской Федерации прошло 1 июля 2020 г. Вопрос в бюллетене звучал

\footnotetext{
${ }^{1}$ В целях ознакомления жителей г. Екатеринбурга с постатейными поправками муниципальное автономное учреждение «Город» по заказу Департамента информационной политики администрации г. Екатеринбурга в июне 2020 г. издало тиражом 600 тыс. экз. брошюру «Моя Конституция».
} 
следующим образом: «Вы одобряете изменения в Конституиию Российской Федерации?» [12].

«Гарантийный» Федеральный закон «Об основных гарантиях избирательных прав и права на участие в референдуме граждан Российской Федерации» в данной кампании не действовал, за исключением некоторых норм, касающихся деятельности избирательных комиссий. Вследствие этого формулировка вопроса, вынесенного на голосование, не проверялась, агитация и ее финансирование не регулировались, наблюдение было ограничено, были задействованы не применяемое в России на федеральных выборах (за исключением отдаленных и труднодоступных местностей) досрочное голосование и опробованное один раз (на выборах в Московскую городскую думу в 2019 г.) электронное голосование. В отличие от референдума, для признания данного общероссийского голосования состоявшимся не требовался уровень явки более $50 \%$.

Поправки, рекомендованные к принятию и включенные в текст законопроекта ко второму чтению, вкупе с поправкам, принятыми в первом чтении, составили «реперные точки» конституционного дискурса.

Выявились несколько позиций, которые отражали типологическую природу СМИ, - официоз, оппозищионная и нейтральная, т. е. позиция, выражавшая или поддержку инициативы (Kremlin.ru, «Российская газета»), или ее критику («Новая газета», Znak.com, Meduza.iо и др.), или нейтральную отстраненность от процесса (ТАСС, РИА «Новости» и другие информационные агентства).

Избирательный кодекс Свердловской области содержит принципы, в соответствии с которыми СМИ обеспечивают гласность при подготовке и проведении выборов (ст. 5), непосредственно регулируют порядок информирования избирателей (ст. 60), проведение опросов общественного мнения (ст. 61), участвуют в информационном обеспечении (ст. 62), в предвыборной агитации (ст. 63), в агитационном периоде (ст. 64), а также определяет особенности проведения агитации на телевидении и радио (ст. 66), в периодической печати (ст. 67), путем публичных мероприятий (ст. 68).

Правовые акты, регулирующие общероссийское голосование по поправкам в Конституцию РФ 1 июля 2020 г., содержали и нормы относительно средств массовой информации.

Избирательная комиссия Свердловской области имеет официальный печатный орган (ст. 2, п. 3) для информирования избирателей, она издает научнопопулярный журнал «Выборы и референдумы» и газету «Уральский выбор», имеет официальное издание «Вестник Избирательной комиссии Свердловской области». Кировская районная территориальная комиссия г. Екатеринбурга выпускала информационный листок «ТИК-Инфо» [25] (редактор В. Лашко).

Центризбиркомом был выбран пакетный вариант голосования - разом по всем более 200 изменениям [21]. Глава ЦИК Э. А. Памфилова заявила, что голосование по каждой поправке отдельно немыслимо с технической точки зрения; сравнила предстоящий плебисцит с «комплексным обедом».

16 марта 2020 г. 128 российских юристов, политологов и правозащитников инициировали и подписали обращение в Совет Европы с требованием провести 
срочную правовую экспертизу изменений в Конституции РФ. Обращение было размещено на сайте Change.org, где оно набрало, по сведениям Znak.com, более 200 тыс. подписей к 27 мая 2020 г. [4]. 27 мая 2020 г. Совет Европы рассмотрел обращение и принял решение направить запрос на экспертизу в Венецианскую комиссию. Венецианская комиссия должна проверить изменения Конституции РФ на соответствие европейским и международным стандартам демократии и верховенства права, а также правовым обязательствам России в рамках Совета Европы [2].

Выставленный на сайте Государственной думы РФ текст поправок в Конституцию РФ просмотрели 8531486 посетителей сайта, 11439 из них поделились с другими. Время чтения текста составило 61 минуту.

Результаты социологических опросов показывали большой разброс прогнозов относительно явки и итогового решения по поправкам. Разницу эксперты связывают с несколькими факторами: с особенностями в формулировках вопросов и изначальной ориентацией на разные аудитории. Опрос ВЦИОМа от 15 июня 2020 г. зафиксировал, что дату проведения общероссийского голосования знают 83 \% респондентов, намерение пойти на голосование высказали 68 \%, не будут голосовать 17 \%.

Наблюдать за голосованием и контролировать его могли три категории участников: члены комиссии с правом решающего голоса, наблюдатели и представители СМИ. Участковые комиссии формировались заранее, наблюдателей на общероссийское голосование могли направлять региональные общественные палаты по заранее поданным заявкам, а представители СМИ должны были иметь договор с редакцией, заключенный не позднее чем за два месяца до назначения голосования. Из постановления ЦИК о порядке голосования по конституционной реформе убрали право журналистов присутствовать при подсчете бюллетеней. Согласно редакции от 2 июня 2020 г., теперь к этому будут допускать только наблюдателей от Общественной палаты [30].

Ряд политических и общественных деятелей начали кампанию против внесения поправок в Конституцию («HET!»: https://2020go.ru). Однако вскоре Роскомнадзор заблокировал сайт кампании [29], но он продолжил свою работу на другом домене.

Критическая позищия оппозиционных СМИ была вызвана тем, что так называемое «обнуление президентских сроков» (термин депутата Государственной думы В. В. Терешковой), т. е. предоставление возможности В. В. Путину остаться президентом после 2024 г., по мнению части политологов, и было главной целью всей затеянной кампании по поправкам. Во втором чтении за поправки В. В. Терешковой проголосовали 380 депутатов Государственной думы, 1 - воздержался, против - 43 [24].

Нейтральная позищия мотивировались тем, что ни закон от 14 марта, ни утвержденный ЦИК порядок голосования никак не регулируют ни агитацию, ни финансирование этой агитации.

Ситуация с журналистами тоже непростая. В «гарантийном» законе есть норма, согласно которой представлять СМИ на участках могут только люди, заключившие с редакцией договор не менее чем за два месяца до назначения выборов. В законе от 14 марта 2020 г. этой нормы нет, а любое ограничение прав граждан 
может вводиться только федеральным законом. Так рассуждали и те члены ЦИК, которые подготовили проект «Порядок аккредитации представителей СМИ». Но под напором заместителя председателя ЦИК Н. Булаева они согласились добавить в «Порядок аккредитации...» то же требование к журналистам и для общероссийского голосования.

Для выборов депутатов эта норма действует давно, так что СМИ может заблаговременно заключить договор с «дополнительными» журналистами. Сейчас такая норма введена фактически задним числом. Само общенародное голосование было назначено президентским указом от 17 марта, а потому было непонятно, будет ли аккредитация отсчитываться от этого времени или от будущего уточнения новой даты.

Общенародное голосование состоялось 1 июля 2020. Центральной избирательной комиссией были представлены сведения о его результатах [23]. Общая явка на голосование составила 65 \%. После обработки 100 \% протоколов было установлено, что за внесение изменений в Основной закон проголосовали 77,92 \% избирателей, против - 21,27 \%. В свою очередь, и Кировская РТИК г. Екатеринбурга 6 июля 2020 г. обнародовала итоги общероссийского голосования по вопросу одобрения изменений в Конституцию Российской Федерации в своем районе. Явка составила 45,98 \% от 158680 граждан, имеющих право голоса. На вопрос «Вы одобряете изменения в Конституцию Российской Федерации?» ответили «Да» 45512 чел. (62,40 \%), «Нет» - 26848 (36,81 \%) [12].

После одобрения в ходе общероссийского голосования изменений в Конституцию Российской Федерации, предусмотренных ст. 1 настоящего Закона, Президент Российской Федерации издал указ об официальном опубликовании Конституции Российской Федерации с внесенными в нее поправками, а также с указанием даты вступления соответствующих поправок в силу. Официальное опубликование Конституции Российской Федерации с внесенными в нее поправками осуществляется незамедлительно после официального опубликования результатов общероссийского голосования. 3 июля 2020 г. Владимир Путин подписал указ «Об официальном опубликовании Конституции Российской Федерации с внесенными в нее поправками» [23].

Конституционный дискурс 2020 г. позволяет нам говорить об инклюзивности СМИ в формирование двух оснований государственной власти: юридического (легализация, законность) и сощиально-психологического (легитимация, т. е. ее обоснованность в представлениях граждан). Степень легализации государственной власти и ее легитимация являются подвижной величиной, особенно вторая (легитимация).

Средства массовой информации участвуют в легализации государственной власти, будучи аффилированными в конституционный и избирательный процессы. В современных условиях конституция принимается путем референдума прямого голосования избирателей за или против проекта.

Конституционный дискурс 2020 г. продемонстрировал гибридный тип легитимации. Со времен немецкого юриста и политолога Макса Вебера (1864-1920) различают «чистые» типы легитимации государственной власти: традиционный, харизматический и рациональный. 
Для самоорганизации государственности важно развитие дискурсивного сознания в обществе и диалогичности культуры. Монологичность в средствах массовой информации, науке, политике, искусстве подрывает нравственное равенство говорящих, участников диалога. Диалог может происходить не только между различными социальными субъектами, но и внутри каждого социального субъекта, в том числе и в сознании каждого отдельного человека $[1,214]$.

В истории политики использовался и используется двойной ряд апелляций. Наряду с обращением к идеальным и практическим, утилитарным аргументам используется апелляция к рациональным и иррациональным доводам $[8,246-$ 251]. Прототипические модели в языках и дискурсах исследовали ученые Института социально-гуманитарных наук Тюменского университета [18].

М. Вебер предложил выделять три типа легитимации: традиционный, т. е. основанный на неписаных законах традиций, обычаев, культуры, догосударственных политических отношениях; харизматический, эмоционально-волевой; ращиональный, основанный на принятых в государстве порядках и законах, разумных суждениях. С этой классификацией Вебер связывает и типологию власти: государственная власть - при ее рациональном обосновании и личная, когда она основана на традиционных и харизматических легитимирующих началах.

В чистом виде эти типы встречаются редко; чаще всего они бытуют в «перекрестных», смешанных формах. Типология М. Вебера приобрела большую популярность, однако в ней не было указаний на содержание легитимирующих апелляций. Исходя из итогов контент-анализа, мы попытались их описать. В табл. 2 по горизонтали обозначены типы апелляций, который анонсирует «инициатор» дискурса. По вертикали обозначены типы апелляций, которые привычны восприятию «слушателя» в соответствии со стереотипом его сознания. На пересечении возникает девять типов апелляции, которые мы описали согласно их основному контенту:

- для традиционного типа легитимации государственности: тотемный, мифологический, мифотворческий;

- для харизматического типа легитимации: мифический, герочческий, повествовательныци;

- для рационального типа легитимации: мифичный, апологетический, информачионный.

Таблица 2

\section{Легитимирующие апелляции дискурса}

\begin{tabular}{l|l|l|l}
\hline \multicolumn{1}{c|}{ Тип апелляции } & \multicolumn{1}{|c|}{ Традиционный } & \multicolumn{1}{|c}{ Харизматический } & \multicolumn{1}{c}{ Рациональный } \\
\hline Традиционный & а) тотемный & б) мифический & в) мифичный \\
Харизматический & г) мифологический & д) героический & е) апологетический \\
Рациональный & ж) мифотворческий & 3) повествовательный & и) информационный
\end{tabular}

Контент-анализ конституционного дискурса обнаруживает соответствие тематики выступлений СМИ с предложениями законопроекта, т. е. раскрывает 
сущность «революции сверху», которая в подробностях разбиралась РИА «Новости» $[20]$ :

- поправки, связанные с историей и политической системой;

- поправки в области традиционных семейных ценностей, прав и свобод человека и гражданина;

- изменение полномочий Федерального собрания;

- расширение полномочий Президента и сокращение полномочий Правительства;

- ограничения в области местного самоуправления;

- поправки, относящиеся к реформе судебной власти;

- отказ от исполнения части решений международных судов.

«Веберовские» типы легитимации на пересечении порождают для СМИ легитимирующие апелляции девяти типов (названия предложены нами. - Aвm.):

а) тотемный, типа «мы с тобой одной крови». В разное время было выдвинуто до 50 теорий тотемизма [27, 250]. Тотемические апелляции представляют собой архаические формы, основанные на вере в тесную родственную связь между определенным видом животного (тотемом) и родовой группой. Символом партии «Единая Россия» выбран медведь². Современная форма репрезентации апелляции тотемного типа - государственный герб России с золотым двуглавым орлом, поднявшим вверх расправленные крылья. На груди орла, в красном щите, - cеребряный всадник в синем плаще на серебряном коне, поражающий серебряным копьем черного, опрокинутого навзничь и попранного конем дракона ${ }^{3}$. Полный герб Свердловской области представляет собой червленый щит с серебряным восстающим соболем, держащим передними лапами золотую стрелу, положенную в столб оперением вверх. На гербе г. Челябинска - в серебряном поле на зеленой земле навьюченный золотой верблюд;

б) мифический; мифическое в культуре воспринимается, во-первых, как древнее сказание о богах и героях; во-вторых, как составная часть религиозного исповедания, легенда, сказание и, наконец, как нечто вымышленное, выдуманное. «Национальный миф по своей природе консервативен. Он культивирует прошлое и апеллирует к традициям, сложившимся некогда в замкнутых, иерархично организованных аграрных обществах» [11, 10-13]. «Приобщение к национальным мифам является методом адаптации людей к новой динамичной, открытой, конфликтной реальности, способом примирения с ней, обнаружения благородных смыслов в повседневных поступках, не укорененных в общественном быте» [Там же, 13];

в) мифичныц; мифичный в отличие мифического значит лишь «вымышленный, выдуманный». Данный тип апелляций появляется на сопряжении

${ }^{2}$ Медведь был тотемным зверем многих славянских племен. Русских сравнивают с медведями из-за их нерасторопности и незлобивости, с одной стороны, и умения постоять за себя - с другой.

${ }^{3}$ Описание герба России в утвержденном Указом Президента России от 30 ноября 1993 г. № 2050 «О Государственном гербе Российской Федерации» одноименном Положении отличается от описания герба России в Федеральном конституционном законе от 25 декабря 2000 г. № 2-ФКЗ «О Государственном гербе Российской Федерации», однако в обоих законах в приложениях приведен один и тот же рисунок герба России. 
иррациональных и рациональных форм отражения реальной действительности. Форма репрезентации - «зов предков»;

г) мифологический; легитимирующие апелляции в данном случае выстроены как совокупность, система мифов. Национальный миф предполагает размежевание между «своими» и «чужими»;

д) герочческий; данный тип апелляций возникает на стыке харизматического способа аргументации и сенсорных способов восприятия. Ссылки на авторитеты, результаты опытов, обращение к историческим и лингвистическим сюжетам, обращение к ранее изданным книгам, силлогический характер изложения - вот основные формальные признаки легитимирующих апелляций;

е) апологетический; осуществляется в виде защиты, устной или письменной, оправдания, восхваления какого-нибудь лица, учения, идеи. Форма репрезентации - оправдание мессианского предназначения того или иного политического лидера;

ж) мифотворческий; апелляции данного типа в большей мере являются результатом творческой деятельности. Национальные мифы необходимы для модернизации общества, ибо они «заново скрепляют разорванную социальную ткань» $[11,13]$;

з) повествовательныци; литературный жанр - портретный очерк, биографическое произведение о деяниях типа «жития святых»;

и) информационныци; форма репрезентации - общественное мнение.

В совокупности легитимирующие апелляции показали транзитивный тренд перехода конституционного дискурса от рациональных легитимаций через эмоционально-волевые к традиционным апелляциям.

Ученые заметили, что на основе дискурсивного поля формируется дискурсивное сообщество. Больше всего поддержали поправки к Конституции:

1. Чеченская Республика - 97,92\%.

2. Республика Тыва - 96,79\%.

3. Республика Крым - 90,07 \%.

4. Республика Дагестан - 89,19\%.

5. Краснодарский край $-88,92 \%$.

Выделилась и пятерка регионов, менее всего поддержавших поправки к Конституции. Особняком здесь стоит Ненецкий автономный округ - единственный регион, где жители сказали в большинстве своем «нет» изменениям ${ }^{4}$. Регионы, где менее всего поддержали поправки:

1. Ненецкий автономный округ - 43,78 \%.

2. Республика Саха (Якутия) - 58,34\%.

3. Камчатский край $-61,76 \%$.

4. Магаданская область - 62,03\%.

5. Омская область - 62,09\%.

\footnotetext{
${ }^{4}$ Как отмечают эксперты, голосовали люди, скорее, против объединения региона с Архангельской областью.
} 
Участие средств массовой информации в обсуждении поправок в Конституцию РФ позволяет назвать несколько направлений деятельности, которые обогатили журналистскую практику:

- показ законодательной инициативы;

- прохождение инициативы по инстанциям;

- выработка формулы голосования;

- формирование комиссий по осуществлению голосования;

- наблюдение за голосованием по поправкам;

- подведение итогов голосования;

- обнародование итогов голосования.

В совокупности формы и методы деятельности редакций показали реализацию средствами массовой информации присущих им функций по формированию российской национальной идентичности.

3 июля 2020 г. Президент Владимир Путин подписал Указ «Об официальном опубликовании Конституции Российской Федерации с внесенными в нее поправками» [15]. Анализ конституционного дискурса 2020 г. важен для теоретической разработки проблем легализации и легитимации государственной власти, путей и способов этого процесса и имеет особое значение в жизни современной России.

1. Бахтин М. М. Проблемы поэтики Достоевского. 4-е изд. М., 1979. 318 с.

2. В Совете Европы рассмотрели петицию россиян о правовой экспертизе поправок в Конституцию // Znak.com. URL: https://www.znak.com/2020-05-27/v_sovete_evropy_rassmotreli_ peticiyu_rossiyan_o_pravovoy_ekspertize_popravok_v_konstituciyu (дата обращения: 26.08.2020).

3. Гайда А. В., Вериинин С. Е., Шульи В. Л. Коммуникация и эмансипация. Свердловск, 1988, $139 \mathrm{c}$.

4. Глухова Н., Тяжлов И. Разрешительное толкование // КоммерсантЪ. 2020. 26 марта.

5. Заключение Конституционного суда Российской Федерации от 16.03.2020. № 1-3. URL: http://publication.pravo.gov.ru/Document/View/0001202003160037 (дата обращения: 26.08. 2020).

6. Изменения в Конституцию приняты в третьем чтении // Государственная дума Федерального Собрания Российской Федерации : [сайт]. URL: http://duma.gov.ru/news/48003/ (дата обращения: 26.08. 2020).

7. Ильин В. И. Потребление как дискурс : учеб. пособие. СПб., 2008. 446 с.

8. Исхаков Р. Л. Слушать и слышать // Государственная национальная политика: проблемы и перспективы. Екатеринбург, 2005. С. 246-251.

9. Итоги Общероссийского голосования по вопросу одобрения изменений в Конституцию Российской Федерации в Кировском районе города Екатеринбурга // Кировская районная территориальная комиссия г. Екатеринбурга : [офиц. сайт]. URL: http://ikso.org/tik/site/ ekaterinburg_kirovskiy/archive/news/show/itogi_obsherossiyskogo_golosovaniya_po_voprosu_ odobreniya_izmeneniy_v_konstituciu_rossiyskoy_federacii_v_kirovskom_rayone_goroda_ekaterinburga/ (дата обращения: 26.08. 2020).

10. Как менялась действующая Конституция России // TACC : [сайт]. URL: https:/tass.ru/ info/7527629 (дата обращения: 26.08. 2020).

11. Национальный вопрос в городском сообществе. Пермь, 2003.

12. О назначении общероссийского голосования по вопросу одобрения изменений в Конституцию Российской Федерации : Указ Президента РФ от 17 марта 2020 г. № 188 // prezident.org : [сайт]. URL: http://prezident.org/articles/ukaz-prezidenta-rf-188-ot-17-marta-2020-goda-17-03-2020. html (дата обращения: 26.08. 2020). 
13. О праздновании 1150-летия зарождения российской государственности : Указ Президента РФ от 03.03. 2011 № 267. URL: http://graph.document.kremlin.ru/page.aspx?1547897 (дата обращения: 22.06. 2015)

14. О совершенствовании регулирования отдельных вопросов организации и функционирования публичной власти // Российская газета. Федер. вып. № 55(8109). 2020. 16 марта.

15. Об официальном опубликовании Конституции Российской Федерации с внесенными в нее поправками : указ // Президент России : [офиц. сайт]. URL: http://www.kremlin.ru/acts/ news/63598 (дата обращения: 29.08. 2020).

16. Памфилова предложила специальный термин для голосования по поправкам в Конституцию // Интерфакс : [сайт]. URL https://www.interfax.ru/russia/692433 (дата обращения: 26.08. 2020).

17. Послание Президента Федеральному Собранию // Президент России : [офиц. сайт]. URL: http://kremlin.ru/events/president/news/62582 (дата обращения: 26.08. 2020).

18. Прототипические модели в языках и дискурсах : монография / [Д. В. Шапочкин и др.]. Тюмень, 2018. $148 \mathrm{c}$.

19. Прохоров Е. П. Введение в теорию журналистики. М., 1995.

20. Революция сверху. Суть предложенных Путиным изменений в Конституцию // РИА Новости : [сайт]. URL: https://ria.ru/20200115/1563458293.html (дата обращения: 26.08. 2020).

21. Референдума по предложенным Путиным поправкам в Конституцию не будет, а будет «всероссийское голосование» // Новости NEWSru.com: [сайт]. URL: http://palm.newsru.com/ russia/16jan2020/golos.html (дата обращения: 26.08. 2020).

22. Российская газета. 1993. 25 дек.

23. Сведения о проводящихся выборах и референдумах : [сайт]. URL: http://www.vybory. izbirkom.ru/region/region/izbirkom?action=show \&root=1\&tvd=100100163596969\&vrn=1001001 $63596966 \&$ region $=0 \&$ global $=1 \&$ sub_region $=0 \&$ prver $=0 \&$ pronetvd $=$ null $\&$ vibid $=10010016359696$ $9 \&$ type=465 (дата обращения: 29.08.2020).

24. Стенограмма заседания 10 марта 2020 г. // Государственная дума : [офиц. сайт]. URL: http://transcript.duma.gov.ru/node/5430/ (дата обращения: 26.08. 2020).

25. Тик-инфо : информ. листок Киров. район. территор. комиссии г. Екатеринбурга. URL: http://ikso.org/tik/site/ekaterinburg_kirovskiy/izdaniya/tik_info (дата обращения: 29.08. 2020).

26. Универсальный словарь иностранных слов русского языка. М., 2001.

27. Философская энциклопедия : в 5 т. М., 1964. Т. 5.

28. Хабриева Т. Я., Чиркин В. Е. Теория современной конституции. М., 2005. 320 с.

29. Хейфеи В. Роскомнадзор сказал первым «Нет»// КоммерсантЪ. 2020. 13 марта.

30. ЦИК отстранил журналистов от наблюдения за подсчетом голосов за поправки в Конституцию // Новая газета. 2020. 4 июня. URL https://novayagazeta.ru/news/2020/06/04/162048-tsikotstranil-zhurnalistov-ot-nablyudeniya-za-podschetom-golosov-za-popravki-v-konstitutsiyu (дата обращения: 26.08. 2020).

31. Чиркин В. Е. Основы государственной власти. М., 1996. 112 с.

32. Habermas J., Luhmann N. Theorie der Gesellschaft oder Sozialtechnologie. Was leistet die Systemforschung? Frankfurt am Main, 1971.

Статья поступила в редакиию 04.09.2020 г. 